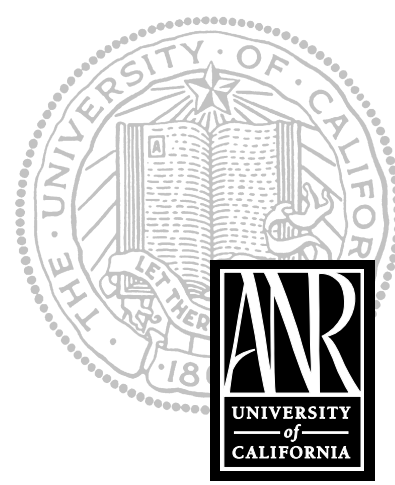

UNIVERSITY OF CALIFORNIA

Agriculture and Natural Resources

http://anrcatalog.ucdavis.edu In partnership with

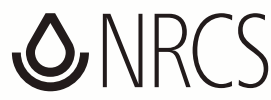

Natural

Resources

Conservation

Service

http://www.nrcs.usda.gov

Farm Water Quality Planning

A Water Quality and Technical Assistance Program for California Agriculture

http://waterquality.ucanr.org

This Reference Sheet is part of the Farm Water Quality

Planning (FWQP) series, developed for a short course that provides training for growers of irrigated crops who are interested in implementing water quality protection practices. The short course teaches the basic concepts of watersheds, nonpoint source pollution (NPS), self-assessment techniques, and evaluation techniques. Management goals and practices are presented for a variety of cropping systems.

\title{
Irrigation Water Salinity and Crop Production
}

STEPHEN R. GRATTAN, Plant-Water Relations Specialist, University of California, Davis

$\mathbf{I}_{\text {rri }}$ wation water quality can have a profound impact on crop production. All irrigation water contains dissolved mineral salts, but the concentration and composition of the dissolved salts vary depending on the source of the irrigation water. For example, snow melt or water supplies from the Sierra Nevada contain very small amounts of salt whereas groundwater or wastewater typically has higher salt levels. Too much salt can reduce or even prohibit crop production while too little salt can reduce water infiltration, which indirectly affects the crop. An understanding of the quality of water used for irrigation and its potential negative impacts on crop growth is essential to avoid problems and to optimize production. For more information on any of the issues found in this publication, please contact your local University of California Cooperative Extension office.

\section{DISSOLVED SALTS}

Dissolved salts in irrigation water form ions. The most common salts in irrigation water are table salt (sodium chloride, $\mathrm{NaCl}$ ), gypsum (calcium sulfate, $\mathrm{CaSO}_{4}$ ), Epsom salts (magnesium sulfate, $\mathrm{MgSO}_{4}$ ), and baking soda (sodium bicarbonate, $\mathrm{NaHCO}_{3}$ ). Salts dissolve in water and form positive ions (cations) and negative ions (anions). The most common cations are calcium $\left(\mathrm{Ca}^{2+}\right)$, magnesium $\left(\mathrm{Mg}^{2+}\right)$, and sodium $\left(\mathrm{Na}^{+}\right)$while the most common anions are chloride $\left(\mathrm{Cl}^{-}\right)$, sulfate $\left(\mathrm{SO}_{4}{ }^{2-}\right)$, and bicarbonate $\left(\mathrm{HCO}_{3}^{-}\right)$. The ratios of these ions, however, vary from one water supply to another. Potassium $\left(\mathrm{K}^{+}\right)$, carbonate $\left(\mathrm{CO}_{3}{ }^{-}\right)$, and nitrate $\left(\mathrm{NO}_{3}{ }^{-}\right)$also exist in water supplies, but concentrations of these constituents are comparatively low. In addition, some irrigation waters, particularly from groundwater sources, contain boron at levels that may be detrimental to certain crops.

It should be noted that substantial salinization potential is realized through natural weathering and dissolution of soil parent materials, and these salt contributions will attenuate or augment irrigation water ionic constituents.

\section{CHARACTERIZING SALINITY}

There are two common water quality assessments that characterize the salinity of irrigation water. The salinity of irrigation water is sometimes reported as the total salt concentration or total dissolved solids (TDS). The units of TDS are usually expressed in milligrams of salt per liter $(\mathrm{mg} / \mathrm{L})$ of water. This term is still used by commercial analytical laboratories and represents the total number of milligrams of salt that would remain after lliter of water is evaporated to dryness. TDS is also often reported as parts per million (ppm) and is the same numerically as $\mathrm{mg} / \mathrm{L}$. The higher the TDS, the higher the salinity of the water.

The other measurement that is documented in water quality reports from commercial labs is specific conductance, also called electrical conductivity (EC). EC is a much more useful measurement than TDS because it can be made instantaneously and easily by irrigators or farm managers in the field. Salts that are dissolved in water 
conduct electricity, and, therefore, the salt content in the water is directly related to the EC. The EC can be reported based on the irrigation water source (ECw) or on the saturated soil extract (ECe). Units of EC reported by labs are usually in millimhos per centimeter $(\mathrm{mmhos} / \mathrm{cm})$ or decisiemens per meter $(\mathrm{dS} / \mathrm{m})$. One $\mathrm{mmho} / \mathrm{cm}=1 \mathrm{dS} / \mathrm{m}$. EC is also reported in micrommhos per centimeter $(\mu \mathrm{mhos} / \mathrm{cm}) .1 \mu \mathrm{mho}=1 / 1000$ mmho.

Often conversions between ECw and TDS are made, but caution is advised because conversion factors depend both on the salinity level and composition of the water. For example:

TDS $(\mathrm{mg} / \mathrm{L})=640 \times \mathrm{ECw}(\mathrm{dS} / \mathrm{m})$ when $\mathrm{ECw}<5 \mathrm{dS} / \mathrm{m}$

TDS $(\mathrm{mg} / \mathrm{L})=800 \times \mathrm{ECw}(\mathrm{dS} / \mathrm{m})$ when ECw $>5 \mathrm{dS} / \mathrm{m}$

Sulfate salts do not conduct electricity in the same way as other types of salts. Therefore, if water contains large quantities of sulfate salts, the conversion factors are invalid and must be adjusted upward.

\section{IRRIGATION WATER SALINITY, SOIL SALINITY, AND LEACH IN G}

Many irrigation water supplies contain a substantial amount of salt. For example, a water source with an EC of $1.0 \mathrm{mmho} / \mathrm{cm}$, a quality suitable for irrigation of most crops, contains nearly 1 ton of salt in every acre-foot of water applied. Irrigation can contribute a substantial amount of salt to a field over the season.

Salts accumulate in the rootzone by two processes: the upward movement of a shallow saline-water table and salts left in the soil due to insufficient leaching. To control salinity from high saline water tables, drains must be installed in the field. To battle against salts that accumulate in the rootzone from the irrigation water, the soil must be adequately leached.

Leaching is the process of applying more water to the field than can be held by the soil in the crop rootzone such that the excess water drains below the root system, carrying salts with it. The more water that is applied in excess of the crop water requirement, the less salinity there is left in the rootzone despite the fact that more salt has actually been added to the field. The term leaching fraction (LF) is used to relate the fraction or percent of water applied to the field that actually drains below the rootzone. For example, if 1 acre-foot of water is applied to 1 acre of land, and 0.1 acre-foot drains below the rootzone, the leaching fraction is $1 / 10$ (10 percent).

Below are some useful relationships between the salinity in irrigation water (electrical conductivity of irrigation water, $\mathrm{ECw}$ ) and the average rootzone salinity (ECe). These relationships were developed by Ayers and Westcot (1985) and assume steady state conditions. ECe is the electrical conductivity of the saturated soil paste (soil samples are saturated with distilled water, the soil water is then extracted, and the EC is measured on the extracted water). These relationships predict what will happen over the long term if the leaching fractions indicated are achieved and assuming that the ECe in the rootzone increases with depth (which would be evidence of leaching).

LF $10 \%$ leads to ECw x $2.1=\mathrm{ECe}$

LF $15-20 \%$ leads to ECw x $1.5=$ ECe

LF $30 \%$ leads to $\mathrm{ECw}=\mathrm{ECe}$ 


\section{ESTIMATING YIELD POTENTIAL}

How could you use these relationships to estimate the yield potential? Maas and Grattan (1999) provide an extensive list of salinity coefficients for a number of horticultural and agronomic crops. These coefficients consist of a threshold and slope. The salinity threshold (a) is the maximum average soil salinity (ECe) the crop can tolerate in the rootzone without a decline in yield. The slope coefficient (b) is the percent loss in relative yield the crop will experience for every unit increase in ECe above the threshold. Using these coefficients, the yield potential (\% Yield) can be estimated from the following expression:

$\%$ Yield $=100-b(E C e-a)$

Tables 1 and 2 provide water quality guidelines for the most commonly grown crops in California. Table 1 assumes that the soil is well drained and that an LF of 15 to 20 percent is achieved. It is based on the formulas above and provides guidelines for trees and vines. Table 2 provides the same type of guidelines for vegetable and row crops. These tables provide the salinity level in the irrigation water $(\mathrm{ECw})$ that, if used continuously to achieve an LF of 15 to 20 percent, would result in yield potentials of $100,90,75$, and 50 percent. The ECw values at $100 \%$ yield represent the poorest quality water that, if used continuously, will produce ECe levels equal to the salinity thresholds. For example, lettuce has the following salinity coefficients:

$\mathrm{a}=1.3 \mathrm{dS} / \mathrm{m}$

and

$\mathrm{b}=13$ when expressed as ECe

If the average rootzone ECe throughout the season was $3.2 \mathrm{dS} / \mathrm{m}$, then the yield potential is 75 percent. If the average rootzone salinity value of 3.2 is then converted to irrigation water salinity assuming an LF of 15 to 20 percent, ECw is $2.1 \mathrm{dS} / \mathrm{m}$. The guidelines also assume that all other factors such as fertility, irrigation scheduling, and pest control are managed to optimize crop performance.

It is important to note that most of the experiments that were used to generate these guidelines were conducted in the interior regions of California where the climate is hot and dry during the summer. Crops grown in the coastal regions where the climate is milder will likely tolerate greater salinities than indicated above. Furthermore, much of the groundwater used for irrigation in coastal areas of California contains high levels of dissolved gypsum, which elevates the salinity of the water. However, crops irrigated with this water do not suffer the same detrimental effects as Cl-dominated waters with an equal EC.

In fields where salinity has increased in the rootzone to damaging levels, reclamation leaching is recommended. A common rule of thumb is that the salinity in the top 1 foot of the rootzone can be reduced 80 to 90 percent by intermittently applying 1 acre-foot of water per acre of land. 
Table 1. Estimated yield of tree and vine crops with long-term use of irrigation water with different levels of soil salinity (potential yields are based on a 15 to 20 percent leaching fraction and do not account for the effects of specific elements)

\begin{tabular}{|c|c|c|c|c|c|}
\hline \multirow[b]{3}{*}{ Tree and vine crops } & \multicolumn{4}{|c|}{ ECw (mmhos/cm) } & \multirow[b]{3}{*}{ Rating $^{2}$} \\
\hline & \multicolumn{4}{|c|}{ Yield potential $^{1}$} & \\
\hline & $100 \%$ & $90 \%$ & $75 \%$ & $50 \%$ & \\
\hline Almond & 1.0 & 1.4 & 1.9 & 2.8 & $S$ \\
\hline Apple & - & - & - & - & $S$ \\
\hline Apricot $^{3}$ & 1.1 & 1.3 & 1.8 & 2.5 & $S$ \\
\hline Avocado $^{3}$ & - & - & - & - & $S$ \\
\hline Blackberry & 1.0 & 1.3 & 1.5 & 2.5 & $S$ \\
\hline Boysenberry & 1.0 & 1.3 & 1.8 & 2.5 & $S$ \\
\hline Cherry & - & - & - & - & $\mathrm{S}$ \\
\hline Date Palm & 2.7 & 4.5 & 7.3 & 12.0 & $\mathrm{~T}$ \\
\hline $\mathrm{Fig}^{3}$ & - & - & - & - & MT \\
\hline Grape $^{3}$ & 1.0 & 1.7 & 2.7 & 4.5 & MS \\
\hline Grapefruit & 1.2 & 1.6 & 2.2 & 3.3 & $S$ \\
\hline Lemon & 1.0 & 1.5 & 2.3 & 3.6 & $S$ \\
\hline Lime & - & - & - & - & $S$ \\
\hline Olive & - & - & - & - & MT \\
\hline Orange & 1.1 & 1.6 & 2.2 & 3.2 & $S$ \\
\hline Peach & 1.1 & 1.5 & 1.9 & 2.7 & $S$ \\
\hline Pear & - & - & - & - & $S$ \\
\hline Pecan & - & - & - & - & MS \\
\hline Persimmon & - & - & - & - & $S$ \\
\hline Pistachio & - & - & - & - & MS-MT \\
\hline Plum & 1.0 & 1.4 & 1.9 & 2.9 & S \\
\hline Pomegranate $^{3}$ & - & - & - & - & MS \\
\hline Walnut $^{3}$ & - & - & - & - & $S$ \\
\hline
\end{tabular}

- Data not available.

Based on data from Maas and Grattan 1999.

Tolerance to soil salinity is rated as sensitive (S), moderately sensitive (MS), moderately tolerant (MT), and tolerant (T).

Tolerance is based on growth or injury rather than yield. 
Table 2. Estimated yield of vegetable and row crops with long-term use of irrigation water of different qualities (potential yields are based on a 15 to 20 percent leaching fraction and do not account for the effects of specific elements)

\begin{tabular}{|c|c|c|c|c|c|c|}
\hline \multirow[b]{3}{*}{ Vegetable and row crops } & \multicolumn{4}{|c|}{ ECw (mmhos/cm) } & & \\
\hline & \multirow[b]{2}{*}{$100 \%$} & \multicolumn{2}{|c|}{ Yield potential $^{1}$} & \multirow[b]{2}{*}{$50 \%$} & \multicolumn{2}{|c|}{ Rating $^{2}$} \\
\hline & & $90 \%$ & $75 \%$ & & Salt & Boron \\
\hline Asparagus & 2.7 & 6.1 & 11.1 & 19.4 & $\mathrm{~T}$ & VT \\
\hline Bean & 0.7 & 1.0 & 1.5 & 2.4 & $S$ & $S$ \\
\hline Beet, red & 2.7 & 3.4 & 4.5 & 6.4 & MT & $T$ \\
\hline Broccoli & 1.9 & 2.6 & 3.7 & 5.5 & MS & MS \\
\hline Cabbage & 1.2 & 1.9 & 2.9 & 4.6 & $\mathrm{M}$ & MT \\
\hline Carrot & 0.7 & 1.1 & 1.9 & 3.0 & $S$ & MS \\
\hline Cauliflower & 1.9 & 2.6 & 3.7 & 5.5 & MS & MT \\
\hline Celery & 1.2 & 2.3 & 3.9 & 6.6 & MS & VT \\
\hline Corn, sweet & 1.1 & 1.7 & 2.5 & 3.9 & MS & VT \\
\hline Cucumber & 1.7 & 2.2 & 2.9 & 4.2 & MS & MS \\
\hline Eggplant & 0.7 & 1.7 & 3.1 & 5.6 & MS & - \\
\hline Lettuce & 0.9 & 1.4 & 2.1 & 3.4 & MS & MS \\
\hline Onion & 0.8 & 1.2 & 1.8 & 2.9 & $S$ & $S$ \\
\hline Pepper & 1.0 & 1.5 & 2.2 & 3.4 & MS & MS \\
\hline Potato & 1.1 & 1.7 & 2.5 & 3.9 & MS & MS \\
\hline Radish & 0.8 & 1.3 & 2.1 & 3.4 & MS & - \\
\hline Spinach & 1.3 & 2.2 & 3.5 & 5.7 & MS & - \\
\hline Squash, scallop & 2.1 & 2.6 & 3.2 & 4.2 & MS & MT \\
\hline Squash, zucchini & 3.1 & 3.8 & 4.9 & 6.7 & MT & MT \\
\hline Strawberry & 0.7 & 0.9 & 1.2 & 1.7 & $S$ & $S$ \\
\hline Sweet potato & 1.0 & 1.6 & 2.5 & 4.0 & MS & - \\
\hline Tomato & 1.7 & 2.3 & 3.4 & 5.0 & MS & $\mathrm{T}$ \\
\hline Turnip & 0.6 & 1.3 & 2.5 & 4.3 & MS & MT \\
\hline
\end{tabular}

- Data not available.

Based on data from Maas and Grattan 1999.

2 Sensitive (S), moderately sensitive (MS), moderately tolerant (MT), tolerant (T), and very tolerant (VT). 


\section{CROP TOXICITY TO SPECIFIC ELEMENTS}

In addition to salinity, some crops are injured by certain elements, notably sodium $\left(\mathrm{Na}^{+}\right)$, chloride $\left(\mathrm{Cl}^{-}\right)$, and boron (B). With drip and furrow irrigation, chloride and sodium injury do not generally occur in vegetable and row crops unless salinity in irrigation water is severe. Leaf injury can occur in strawberries, however, particularly under hot, dry conditions. Under sprinkler irrigation, injury may occur to wetted leaves of susceptible plants such as pepper, potatoes, and tomato if the ECw exceeds $1.5 \mathrm{mmhos} / \mathrm{cm}$.

Some vegetable and row crops are sensitive to boron. Generally, leaf injury must be severe to cause reduced yields and crop quality. Long-term use of irrigation water containing more than $0.5 \mathrm{ppm}$ boron can reduce the yields of bean, onion, garlic, and strawberry; $0.7 \mathrm{ppm}$ can reduce the yields of broccoli, carrot, potato, and lettuce; and concentrations greater than $2 \mathrm{ppm}$ can reduce yields of cabbage and cauliflower.

Under cool, moist climatic conditions, greater levels of boron can be tolerated, and for short-term use, boron levels given here can be doubled. In addition, soil properties influence the time it takes for injury to occur. The finer the soil texture, the longer it will take for injury to occur.

Unlike most annual crops, tree and vine crops are generally sensitive to boron, chloride, and sodium toxicity. Tolerances vary among varieties and rootstocks. Tolerant varieties and rootstocks resist the uptake and accumulation of toxic ions in the stem and leaf tissue. Continued use of irrigation water with boron concentrations in excess of $0.75 \mathrm{ppm}$ can reduce the yields of grapes and many deciduous tree and fruit crops. This represents a threshold concentration and does not imply that irrigation water with boron at or slightly above this level cannot be used successfully.

Chloride moves readily with the soil water and is taken up by the roots. It is then transported to the stems and leaves. Sensitive berries and avocado rootstocks can tolerate only up to $120 \mathrm{ppm}$ of chloride, while grapes can tolerate up to $700 \mathrm{ppm}$ or more.

The ability of a tree to tolerate sodium varies considerably. Sodium injury on avocado, citrus, and stone-fruit trees has been reported at concentrations as low as $115 \mathrm{ppm}$. Initially, sodium is retained in the roots and lower trunk, but after 3 to 4 years the conversion of sapwood to heartwood apparently releases the accumulated sodium, which then moves to the leaves causing leaf burn.

\section{INFILTRATION OF IRRIGATION WATER}

There are two water quality parameters to consider when assessing irrigation water quality for potential water infiltration problems. These are the ECw and the sodium adsorption ratio (SAR). The SAR is an indicator of the amount of sodium in the water relative to calcium and magnesium. The higher the ratio of sodium to calcium plus magnesium, the higher the SAR. Both a low salt content (low ECw) and high SAR can mean there is a high potential for permeability or water infiltration problems.

A low ECw or high SAR can act separately or collectively to disperse soil aggregates, which in turn reduces the number of large pores in the soil. These large pores are responsible for aeration and drainage. A negative effect from the breakdown of soil aggregates is soil sealing and crust formation. Below is a table that can be used to assess the likelihood of potential water infiltration problems based on both ECW and SAR. 
Table 3 indicates that water infiltration problems are likely if the ECw is less than $0.3 \mathrm{mmho} / \mathrm{cm}$ regardless of the SAR. For example, if the ECw falls below 0.3 $\mathrm{mmho} / \mathrm{cm}$, infiltration rates can drop to less than 0.1 inch per hour. An infiltration rate of 0.1 inch per hour would require 30 hours for a full irrigation of 3 inches to infiltrate the soil. Therefore, pure water or very high-quality water such as that in the Friant-Kern Canal (ECw 0.05 and SAR 0.6) will cause infiltration problems even when applied on soils with high sand content.

The good news is that infiltration problems due to low salt content or high SAR can easily be improved by the addition of gypsum to either the irrigation water or soil. When the irrigation water comes into contact with gypsum, it dissolves into $\mathrm{Ca}^{2+}$ and $\mathrm{SO}_{4}{ }^{2-}$ ions that slightly increase the salinity of the water while simultaneously reducing the SAR. The $\mathrm{Ca}^{2+}$ cations are then free to displace $\mathrm{Na}^{+}$cations adsorbed onto the negatively charged clay particles, thereby enhancing flocculation, improving soil structure, and increasing the water infiltration rate.

Estimating the amount of gypsum to be applied to the irrigation water can be achieved by calculating how much $\mathrm{CaSO}_{4}$ is needed to increase the EC or decrease the SAR. For example, Friant-Kern Canal water has an average ECw of only 0.05 $\mathrm{mmho} / \mathrm{cm}$ and SAR of 0.6. By adding $6 \mathrm{meq} / \mathrm{L} \mathrm{Ca}^{2+}$ (equivalent to 1,400 lb pure gypsum per acre-ft), the ECW will increase to 0.65 and SAR will drop to 0.2 . According to table 3 , this will substantially improve the quality of this water in terms of reducing its permeability hazard.

Determining how much gypsum to add to the soil is a bit more complicated than determining how much to add to the irrigation water. The amount to apply depends on the soil, how much sodium is adsorbed onto the clay surfaces, how much $\mathrm{Ca}^{2+}$ is needed to replace the adsorbed $\mathrm{Na}^{+}$, and to what depth you intend to reclaim the soil. Usually, no more than 1 to 2 tons of gypsum per acre should be applied at any one time. Lighter, more frequent applications of gypsum tend to be more effective than a single heavy application.

Table 3. Combined effect of electrical conductivity (ECW) of irrigation water and sodium adsorption ratio (SAR) on the likelihood of water infiltration (permeability) problems

\begin{tabular}{lcc}
\hline \multirow{2}{*}{$\begin{array}{l}\text { Sodium adsorbtion ration } \\
\text { (SAR) of irrigation or soil }\end{array}$} & \multicolumn{2}{c}{ Water infiltration problem } \\
\cline { 2 - 3 } & Unlikely when $\mathbf{E C w}(\mathbf{d S} / \mathbf{m})$ is more than & Likely when $\mathbf{E C w}(\mathbf{d S / m})$ is less than \\
\hline $0-3$ & 0.6 & 0.3 \\
$3-6$ & 1.0 & 0.4 \\
$6-12$ & 2.0 & 0.5 \\
$12-20$ & 3.0 & 1.0 \\
$20-40$ & 5.0 & 2.0 \\
\hline
\end{tabular}

Source: Ayers and Westcot 1985. 


\section{OTHER WATER QUALITY CONSTITUENTS}

Irrigation water supplies, particularly those from wells, can contain other constituents that may affect water quality. Of particular concern are nitrate $\left(\mathrm{NO}_{3}{ }^{-}\right)$and bicarbonate $\left(\mathrm{HCO}_{3}{ }^{-}\right)$.

Nitrates are often measured as $\mathrm{NO}_{3}-\mathrm{N}$, which refers to the nitrogen concentration in the water that is in the nitrate form. From a public health perspective, there are concerns when excessive levels of nitrates are found in domestic wells. The public drinking water standard is set at $10 \mathrm{mg} / \mathrm{L}$ (or ppm) $\mathrm{NO}_{3}-\mathrm{N}$. From an irrigation perspective, $\mathrm{NO}_{3}^{-}$ in the groundwater can be viewed as a resource. For example, 27 pounds of nitrogen is applied to a field with each acre-foot of water if the water supply contains $10 \mathrm{ppm} \mathrm{NO}_{3}$ $\mathrm{N}$ (45 ppm when expressed as $\mathrm{NO}_{3}^{-}$). It is important that the grower with water of such quality reduces the nitrogen application rates in the field accordingly to accommodate this extra input of nitrogen. Should this be ignored, there may be problems associated with excessive vegetative growth and contamination of the groundwater.

Excessive amounts of bicarbonate can also be problematic. In fields that are irrigated with low-pressure systems, such as drip or mini-sprinklers, calcite or scale can build up near the orifice of the sprinkler or emitter, which can reduce the water discharge. This type of problem can be corrected by injecting acid-forming materials (such as sulfuric acid) in the irrigation water. In addition, bicarbonate could increase the SAR of the soil water by precipitating calcium and magnesium. This can be corrected by frequent gypsum applications to the soil surface.

\section{REFEREN CES}

Ayers, R. S., and D. W. Westcot. 1985. Water quality for agriculture. Food and Agricultural Organization (FAO) of the United Nations. FAO Irrigation and Drainage Paper 29.

Maas, E. V., and S. R. Grattan. 1999. Crop yields as affected by salinity. In R. W. Skaggs and J. van Schilfgaarde, eds., Agricultural Drainage. Agron. Monograph 38. ASA, CSSA, SSSA, Madison, WI.

Hanson, B., S. R. Grattan, and A. Fulton. 1999. Agricultural salinity and drainage. Oakland: University of California Division of Agriculture and Natural Resources Publication 3375. 


\title{
FOR MORE INFORMATION
}

You'll find detailed information on many aspects of turfgrass management in these titles and in other UC ANR products:

Agricultural Salinity and Drainage, Publication 3375

Irrigation and Drainage, Slide Set 93/105

Drip Irrigation for Row Crops, Publication 3376

To order these products, visit our online catalog at http://anrcatalog.ucdavis.edu You can also place orders by mail, phone, or fax, or request a printed catalog of publications, slide sets, and videos from

\author{
University of California \\ Agriculture and Natural Resources \\ Communication Services \\ 6701 San Pablo Avenue, 2nd Floor \\ Oakland, CA 94608-1239
}

Telephone: (800) 994-8849 or (510) 642-2431

FAX: (510) 643-5470

E-mail inquiries: danrcs@ucdavis.edu

An electronic version of this publication is available on the ANR Communication Services website at http://anrcatalog.ucdavis.edu

\section{Publication 8066}

(C)2002 by the Regents of the University of California, Division of Agriculture and Natural Resources. All rights reserved.

The University of California prohibits discrimination against or harassment of any person employed by or seeking employment with the University on the basis of race, color, national origin, religion, sex, physical or mental disability, medical condition (cancer-related or genetic characteristics), ancestry, marital status, age, sexual orientation, citizenship, or status as a covered veteran (special disabled veteran, Vietnam-era veteran or any other veteran who served on active duty during a war or in a campaign or expedition for which a campaign badge has been authorized). University Policy is intended to be consistent with the provisions of applicable State and Federal laws.

Inquiries regarding the University's nondiscrimination policies may be directed to the Affirmative Action/Staff Personnel Services Director, University of California, Agriculture and Natural Resources, 300 Lakeside Drive, 6th floor, Oakland, CA 94612-3550; (510) 987-0096. For a free catalog of other publications, telephone (800) 994-8849. For help downloading this publication, call (530) 754-5112.

pr-06/02-GM/VFG

ISBN 978-1-60107-244-3

This publication has been anonymously peer reviewed for technical accuracy by University of California scientists and other qualified professionals. This review process was managed by the ANR Associate Editor for Natural Resources. 